Agro-Science Journal of Tropical Agriculture, Food, Environment and Extension Volume 20 Number 1 (January 2021) pp. $25-30$

ISSN 1119-7455

\title{
CARCASS AND ORGAN CHARACTERISTICS OF FINISHING BROILERS FED DIETS CONTAINING PROBIOTICS (Saccharomyces cerevisiae)
}

\author{
Ugwuoke J.I., Okwesili O.R., *Dim C.E., Okonkwo M.N. and Ndofor-Foleng H.M. \\ Department of Animal Science, University of Nigeria, Nsukka, Nigeria \\ *Corresponding author's email: chinonso.dim@unn.edu.ng
}

\begin{abstract}
A five-week study was conducted to determine the effect of feeding varying levels of S. cerevisiae on carcass and organ characteristics of finishing broilers. One hundred and twenty 4-weeks old broilers of cobb strain were randomly assigned to four treatments $\left(\mathrm{T1}=0.6 \mathrm{~g}\right.$ Saccharomyces cerevisiae $(\mathrm{SC}) \mathrm{kg}^{-1} \mathrm{diet} ; \mathrm{T} 2=0.8 \mathrm{~g}$

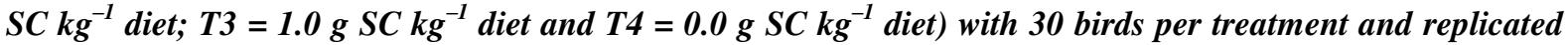
twice with 15 birds per replicate in a completely randomized design. Feed and water were provided ad libitum to the birds in a deep litter system. In the end, data on growth, carcass and organ indices generated from the study were analyzed using one-way analysis of variance (ANOVA). Results showed no significant difference $(p>0.05)$ among the treatments in the birds' growth performance indices. However, significant differences $(p<0.05)$ were observed in the birds' values for liver weight, heart weight, shank length and thigh length with birds in T3 recording highest values of $61.30 \mathrm{~g}, 16.93 \mathrm{~g}$ and $12.00 \mathrm{~cm}$ for liver weight, heart weight and thigh length, respectively. It was thus concluded that finishing broilers fed $1.0 \mathrm{~g}$ of $\mathrm{S}$. cerevisiae had superior carcass and organ characteristics than birds on the control and lower levels of inclusion.
\end{abstract}

Key words: animal protein, direct-fed microbials, fungi, chicken meat, yeast

\section{INTRODUCTION}

Poultry meat production still ranks as one of the most evolving industries in the world (Berri, 2001; 2007). Despite this status, it has not been able to meet the demand of the ever increasing human population, who depend directly on the meat for animal protein and consequently essential amino acids. In a bid to boost productivity, several dietary manipulations have been carried out on poultry, ranging from inclusion of growth promoters (Barreto et al., 2008; Mokhtari et al., 2010), hormones (Al-Dobaib and Mousa, 2009), organic acids (Ghazalah et al., 2011), enzymes (Chuka, 2014; Hossain et al., 2014), locally sourced additives (Onyimonyi et al., 2012; Olabode et al., 2013; Dim et al., 2018), etc.

Because most of these growth enhancers are either carcinogenic or have a residual carryover effect with the attendant health implications in man (Al-Dobaib and Mousa, 2009; Camila et al., 2012), it is therefore pertinent to search for their alternatives which will not only enhance growth of the birds but also ensure safe meat for the consuming populace. A popular alternative is the use of probiotics, which has been proven in poultry to compete and exclude bacterial pathogens in the gastrointestinal tract of the birds (Murry et al., 2004;
Abudabos et al., 2013; Baldwin et al., 2018), agglutinate harmful bacteria such as Salmonella (La Ragione and Woodward, 2003; Murry et al., 2004), encourage complete absorption of nutrients by the birds' gut (Mountzouris et al., 2010; Murshed and Abudabos, 2015), degrade fibrous resources in poultry feeds (Adejumo et al., 2005; Oyedeji et al., 2008) and also muster essential amino acids, vitamins and trace minerals required for the most favorable growth of the animal (Choi et al., 2013; Zhang and Kim, 2014; Podolian, 2017).

Probiotics have been defined by several authors as live microorganisms that have beneficial effects on the host animal when administered (Ahmad, 2006; Ezema, 2013; Ritzi et al., 2014; Aalaei et al., 2019). Over the last decade, the use of probiotics in animal nutrition has gained so much attention and aroused growing research interest in the field of nutrigenomics. Microorganisms used in the formulation of probiotics are mostly of bacteria origin but can also be fungi-based. The use of fungi-based probiotics in the diets of food animals has been demonstrated to improve the quality of feed and performance of the animals (Shen, et al., 2009; Berrin, 2011; Ezema, 2012; Chuka, 2014; Hassan and Mohammed, 2014).

Please cite as: Ugwuoke J.I., Okwesili O.R., Dim C.E., Okonkwo M.N. and Ndofor-Foleng H.M. (2021). Carcass and organ characteristics of finishing broilers fed diets containing probiotics (Saccharomyces cerevisiae). Agro-Science, 20 (1), 25-30. DOI: https://dx.doi.org/10.4314/as.v20i1.5 
Saccharomyces cerevisiae (yeast) is a fungus that serves as an innate ingredient in human diets as bread or fermented beverage (Walker and Stewart, 2016; Shim et al., 2007). It has shown to have probiotic effect when included in the diets of farm animals (Onwurah et al., 2014; Ghazanfar et al., 2015; Sharif et al., 2018; Osita et al., 2019). It has biologically valuable proteins (Choi et al., 2013; Podolian, 2017), soluble fiber (Yamada and Sgarbieri, 2005), minerals, B-complex vitamins, and unique immuno-modulatory properties (Hana et al., 2015). Different dietary inclusion levels of $S$. cerevisiae have been reported to have various effects on the performance of poultry species (Ghosh et al., 2012; Reisinger et al., 2012; Huff et al., 2013; Onwurah et al., 2014; Sharif et al., 2018). This study was therefore aimed at ascertaining the dietary inclusion level of yeast (S. cerevisiae) that would support superior carcass and organ characteristics of finishing broilers in the tropics.

\section{MATERIALS AND METHODS}

\section{Experimental Site and Ethical Approval}

The study was situated in the poultry unit of the Department of Animal Science Teaching \& Research Farm, University of Nigeria, Nsukka. In the report of Momoh et al. (2010), Nsukka was documented to be located in longitude $07^{\circ} 54 \mathrm{E}$ and latitude $05^{\circ}$ $22 \mathrm{~N}$, with annual rainfall range of $966-2098 \mathrm{~mm}$, a mean daily temperature of $26.8{ }^{\circ} \mathrm{C}$ and relative humidity percentage values that ranges from 6580\% (Agbagha et al., 2000). The experiment adhered strictly to the provisions of the Ethical Committee on the use of animals and humans for biomedical research of the University of Nigeria, Nsukka.

\section{Experimental Diets}

The percentage compositions of the experimental diets were presented in Table 1. Samples of the diets were analyzed for their proximate composition according to AOAC (2006) methods and presented in Table 2. Table 3 also presents the proximate composition of the $S$. cerevisiae used in the study.

Experimental Birds, Management and Duration One hundred and twenty (120) four-week-old broilers (cobb strain) were randomly allocated to four groups of 30 birds each and replicated twice with 15 birds per replicate. They birds were brooded according to their respective groups from day-old to $28^{\text {th }}$ day of age before commencing treatment trials. Broilers were randomly assigned to the experimental treatments thus: $\mathrm{T} 1=0.6 \mathrm{~g}$ of $S$. cerevisiae $\mathrm{kg}^{-1}$ of feed, $\mathrm{T} 2=0.8 \mathrm{~g}$ of $S$. cerevisiae $\mathrm{kg}^{-1}$ of feed, T3 $=1.0 \mathrm{~g}$ of $S$. cerevisiae $\mathrm{kg}^{-1}$ of feed and $\mathrm{T} 4=$ feed without $S$. cerevisiae, using a completely randomized design (CRD). The birds received the test organism ( $S$. cerevisiae) from 28 days of age till the termination of the study. Feed and water were supplied ad libitum to the birds. The birds were vaccinated against New Castle disease (Intraocular-Lasota), Gumboro disease (Intraocular) and fowl pox (Intraocular) at weeks one and three, two and four, and five, respectively. Prophylactic treatment against coccidiosis was also given to the birds using Embazin forte ${ }^{\circledR}$ (manufacturer's recommended dosage) at $2^{\text {nd }}$ and $5^{\text {th }}$ weeks of age. The study lasted for 5 weeks during which feed intake, weight gain, and feed conversion ratio (FCR) were properly recorded.

At the end of the feeding trials of the study, 2 birds per replicate were sampled for the carcass and organ yield for all the treatment groups.

\section{Statistical Analysis}

Data were subjected to analysis of variance (ANOVA) using the Statistical Package for Social Sciences (SPSS) version 20.0. Significantly different means were separated using Duncan's New Multiple Range Test (DNMRT) as described by Obi (2002).

Table 1: Percentage compositions of the experimental diets

\begin{tabular}{|c|c|c|}
\hline & Starter & Finisher \\
\hline Ingredients & $\%$ & $\%$ \\
\hline Maize & 51.0 & 53.0 \\
\hline Wheat offal & 6.0 & 10.0 \\
\hline Palm kernel cake & 5.2 & 5.5 \\
\hline Groundnut cake & 21.0 & 15.0 \\
\hline Fish meal & 1.8 & 1.5 \\
\hline Soy bean meal & 10.0 & 10.0 \\
\hline Bone meal & 4.0 & 4.0 \\
\hline Salt & 0.25 & 0.25 \\
\hline Lysine & 0.25 & 0.25 \\
\hline Methionine & 0.25 & 0.25 \\
\hline Vitamin premix & 0.25 & 0.25 \\
\hline Total & 100 & 100 \\
\hline \multicolumn{3}{|l|}{ Calculated composition } \\
\hline Crude protein (\%) & 23.08 & 20.1 \\
\hline Crude fibre $(\%)$ & 4.02 & 5.28 \\
\hline Gross Energy (MCal/kg) & 2.8 & 2.72 \\
\hline \multicolumn{3}{|c|}{ 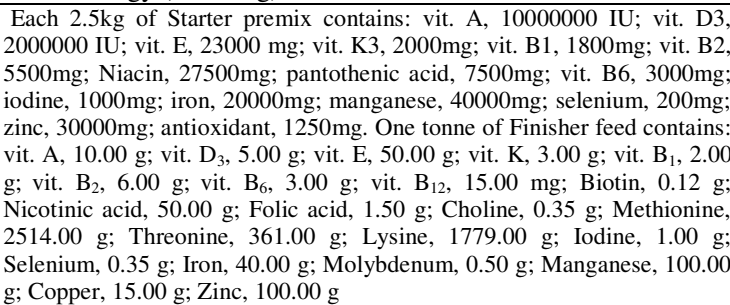 } \\
\hline
\end{tabular}

Table 2: Proximate compositions of the experimental diets

\begin{tabular}{lcc}
\hline Composition & Starter & Finisher \\
\hline Crude protein $(\%)$ & 23.42 & 20.85 \\
Ash $(\%)$ & 5.33 & 6.13 \\
Ether extract $(\%)$ & 4.39 & 5.74 \\
Crude fiber $(\%)$ & 2.10 & 2.62 \\
Moisture $(\%)$ & 8.72 & 7.90 \\
Nitrogen free extract $(\%)$ & 56.04 & 56.76 \\
Gross energy $(\mathrm{kCal} / \mathrm{g})$ & 2940 & 2700 \\
\hline
\end{tabular}

Table 3: Proximate composition of S. cerevisiae

\begin{tabular}{lc}
\hline Composition & Value \\
\hline Dry matter $(\%)$ & 92.87 \\
Calcium $(\%)$ & 0.11 \\
Ether extract $(\%)$ & 1.09 \\
Crude fiber $(\%)$ & 2.50 \\
Phosphorus $(\%)$ & 1.20 \\
Metabolizable energy $(\mathrm{kCal} / \mathrm{kg})$ & 1970 \\
Crude protein $(\%)$ & 41.00 \\
\hline
\end{tabular}




\section{RESULTS AND DISCUSSION \\ Growth Performance of Broiler Chickens Fed Diets Containing Varying Inclusion Levels of Saccharomyces cerevisiae}

Table 4 shows the growth performance of broiler chickens on varying dietary inclusion levels of $S$. cerevisiae. Results showed non-significant $(p>0.05)$ differences among the treatment means for all the growth performance indices studied. The final body weight and average daily weight gain of $\mathrm{T} 1$ were observed to be highest numerically compared to other treatment groups. Too, T1 consumed more feed than others. With respect to FCR, T3 performed the best amongst the treatment groups. Each group recording values within the range published by Udeh et al. (2015) for broilers of same age. The non-significant difference in the growth performance of birds recorded in the current study suggests that $S$. cerevisiae plays little or no significant role in stimulating growth response in finishing broilers at the inclusion levels used in the present study. This result disagrees with several authors (Oyedeji et al., 2008; Afsharmanesh et al., 2010; Yalcin et al., 2013; Chuka, 2014; Onwurah et al., 2014; Yasar and Yegen, 2017) who recorded outstanding growth performances in poultry birds when fed $S$. cerevisiae. Although their reports indicated that the dietary administrations of $S$. cerevisiae were done with day-old chicks, the introduction of $S$. cerevisiae in the diets of the birds in the current study was done at the finishing phase of the birds. Similar to the present study, Ahmed et al. (2015) observed non-significant growth responses in broiler chicks fed varying inclusion levels of $S$. cerevisiae. Therefore, it can be argued that the additive (S. cerevisiae) had less time in the gastrointestinal tract of the birds under study during their growth phases, to efficiently colonize the gut and consequently stimulate positive growth response. Brummer et al. (2010) and Roto et al. (2015) had demonstrated the effects of $S$. cerevisiae on the gut morphology and micro-biota of broiler chickens, linking the early colonization of the probiotic organism in the gut to the improved performance observed in the birds.

\section{Carcass and Organ Characteristics of Broiler Chickens Fed Varying Inclusion Levels of Saccharomyces cerevisiae}

The carcass characteristics and organ weights of finishing broiler chickens fed varying inclusion levels of $S$. cerevisiae are presented in Table 5 . Results indicated significant $(p<0.05)$ differences among the treatments with respect to liver and heart weights as well as shank and thigh lengths. However, non-significant $(p>0.05)$ differences were recorded in the birds' live, dressed and kidney weights. Despite the non-statistical significance, the dressed weight values of birds studied were within the range reported by Olawumi and Fagbuaro (2011) for commercial breeds of broilers in Nigeria. Ojedapo et al. (2015) also documented similar range of values for cobb broilers, at same age as birds from present study, while delineating the variation of broiler chickens in relation to genotype and age of slaughter on carcass indices. Birds on T3 had the highest liver weights which were statistically $(p<0.05)$ different from other treatment groups. Birds on the control group had the least liver weight among the treatment groups, clearly implicating the test organism in conditions leading to increased liver weights. These liver weight values (T3 and T4) were statistically similar to those of T1 and T2. However, liver weights of birds on $\mathrm{T} 1$ and $\mathrm{T} 2$ were statistically similar. The heart weights of birds on $\mathrm{T} 3$ were observed to be the highest and significantly $(p<0.05)$ different from other treatment groups whereas T4 (control) which was statistically similar to T1 had the least values. From the results, it can be suggested that the birds on $S$. cerevisiae experienced hepatomegaly as can be evidenced in their higher liver weight values than the control. This could be linked to possible intrinsic or extrinsic factors that leads to cardiac diseases. The high heart weight values observed in birds on $S$. cerevisiae inclusion suggests that the test additive might be implicated in myocardial hypertrophy. It could be that the $S$. cerevisiae produced "plus metabolites" that exacerbated stressor factors or central defects in the birds leading to myocardial hyperplasia, which can

Table 4: Growth performance of broiler chickens fed varying inclusion levels of Saccharomyces cerevisiae

\begin{tabular}{|c|c|c|c|c|c|}
\hline Parameters & $\mathrm{T} 1(0.6 \mathrm{~g})$ & $\mathrm{T} 2(0.8 \mathrm{~g})$ & $\mathrm{T} 3(1.0 \mathrm{~g})$ & T4 (control) & p-value \\
\hline Initial body weight $(\mathrm{g})$ & 700.00 & 700.05 & 702.05 & 704.05 & - \\
\hline Final body weight (g) & 2460.00 & 2400.00 & 2402.00 & 2404.00 & 0.10 \\
\hline Average daily weight gain, ADWG (g) & 50.28 & 48.57 & 48.57 & 48.57 & 0.07 \\
\hline Total feed intake $(\mathrm{g})$ & 4400.00 & 4210.00 & 4200.00 & 4240.00 & 0.23 \\
\hline Average daily feed intake, ADFI (g) & 125.71 & 120.28 & 120.00 & 121.14 & 0.19 \\
\hline Feed conversion ratio & 2.50 & 2.48 & 2.47 & 2.49 & 0.44 \\
\hline
\end{tabular}

Table 5: Carcass and organ characteristics of broiler chickens fed varying inclusion levels of Saccharomyces cerevisiae

\begin{tabular}{|c|c|c|c|c|c|}
\hline Parameters & T1 $(0.6 \mathrm{~g})$ & $\mathrm{T} 2(0.8 \mathrm{~g})$ & T3 $(1.0 \mathrm{~g})$ & T4 (control) & $\mathrm{p}$-value \\
\hline Live weight (kg) & 2.46 & 2.40 & 2.40 & 2.40 & 0.10 \\
\hline Dressed weight $(\mathrm{kg})$ & 1.77 & 1.82 & 1.85 & 1.77 & 0.19 \\
\hline Liver weight $(\mathrm{g})$ & $53.67^{\mathrm{ab}}$ & $58.35^{\mathrm{ab}}$ & $61.30^{\mathrm{a}}$ & $47.87^{\mathrm{b}}$ & 0.04 \\
\hline Kidney weight (g) & 2.38 & 2.80 & 2.50 & 2.47 & 0.06 \\
\hline Heart weight $(\mathrm{g})$ & $10.10^{\mathrm{c}}$ & $13.33^{\mathrm{b}}$ & $16.93^{\mathrm{a}}$ & $9.37^{\mathrm{c}}$ & 0.05 \\
\hline Shank length $(\mathrm{cm})$ & $7.33^{\mathrm{b}}$ & $7.67^{\mathrm{b}}$ & $7.33^{\mathrm{b}}$ & $9.67^{\mathrm{a}}$ & 0.02 \\
\hline Thigh length $(\mathrm{cm})$ & $10.00^{\mathrm{b}}$ & $11.00^{\mathrm{ab}}$ & $12.00^{\mathrm{a}}$ & $9.33^{\mathrm{b}}$ & 0.00 \\
\hline
\end{tabular}


also give rise to sudden myocardiopathy. The shank length value of T4 was the highest and statistically $(p<0.05)$ different from other treatment groups. Birds on T1 and T3 had the least values for shank length across the treatment means and were statistically $(p<0.05)$ similar with T2. However, the thigh length of T3 was the highest ( $p$ $<0.05)$ among the groups, despite having statistical $(p<0.05)$ similarity with T2. There was no statistical $(p<0.05)$ difference between T1 and T4 whereas they were similar to T2. Nevertheless, birds on the control group (T4) had the shortest thigh length when compared across the groups. In the current study, birds on the control group became visibly taller than the birds on the test additive ( $S$. cerevisiae) owing to their higher shank length values. This suggests that $S$. cerevisiae could have played a negative role in calcium metabolism and of course, bone-mineralization. This negates the reports of Ghasemi et al. (2006) and AkhavanSalamat et al. (2011) who had earlier documented improved mineral retention and bone mineralization in broilers fed yeast. Moreover, the increased thigh length values observed in birds on $S$. cerevisiae could be attributed to the role of the test additive in protein synthesis and muscle formation. Increased thigh length consequently translates to increased surface area for muscle coverage in the thigh region of the birds. Therefore, it can be suggested that the birds on $S$. cerevisiae had better bone density and muscle mass to fill up their improved thigh lengths. The carcass traits recorded in the present study are within the range reported by Singh and Pathak (2016) for cobb broilers while running a comparative carcass assessment of various indigenous chickens. Nonetheless, the reports of Paryad and Mahmoudi (2008), Onwurah et al. (2014) and Ahmed et al. (2015) concur with the findings of the present study as they recorded excellent carcass characteristics of broiler birds fed $S$. cerevisiae.

\section{CONCLUSION AND RECOMMENDATION}

From the results presented in the tables above, it can be concluded that the inclusion of Saccharomyces cerevisiae in the diets of finishing broilers at the levels used in the present study did not improve the growth performance indices studied. However, the dietary inclusion of Saccharomyces cerevisiae at $1.0 \mathrm{~g} \mathrm{~kg}^{-1}$ in the diet of finishing broilers supported significant organ weights of heart and liver and also maintained better carcass characteristics than the birds on the control group. The increased awareness of the general public on the consumption of organ meats over staple meats due to heart and other health implications, made the present study apt and of paramount significance. Thus, the use of Saccharomyces cerevisiae in broiler production should be encouraged at the dietary inclusion level of $1.0 \mathrm{~g} \mathrm{~kg}^{-1}$ starting from the first day of the birds' age in order to achieve maximum productive potentials in the birds.

\section{REFERENCES}

Aalaei M., Khatibjoo A., Zaghari M., Taherpou K., Akbari-Gharaei M. and Soltani M. (2019). Effect of single and multistrain probiotics on broiler breeder performance, immunity and intestinal toll-like receptors expression. J. Appl. Anim. Res., 47 (1), 236-242. https://doi.org/10. 1080/09712119.2019.1618311

Abudabos A., Alyemni A. and Al Marshad B.A. (2013). Bacillus subtilis PB6 based-probiotic $\left(\mathrm{CloSTAT}^{\mathrm{TM}}\right)$ improves intestinal morphological and microbiological status of broiler chickens under Clostridium perfringens challenge. Int. J. Agric. Biol., 15 (6), 978-982

Adejumo D.O., Onifade A.A., Olutende T.O. and Babatunde G.M. (2005). The effects of concentration, age and duration of feeding supplemental yeast (Levucel SB) in a high fiber diet on the performance of broiler chickens. J. Sus. Trop. Agric. Res., 13, 58-65

Afsharmanesh M., Barani M. and Silversides F.G. (2010). Evaluation of wet-feeding wheat-based diets containing Saccharomyces cerevisiae to broiler chickens. Br. Poult. Sci., 51 (6), 776-783. DOI: 10.1080/00071668.2010.531006

Agbagha F.M., Ezema F.U. and Omeke B.C.O. (2000). Studies of management effects on fertility purebreds and crossbred exotic gilts in two breeding farms at Nsukka. Nig. J. Anim. Prod., 28 (1), 20-21

Ahmad I. (2006). Effect of probiotics on broilers performance. Int. J. Poult. Sci., 5 (6), 593-597

Ahmed M.E., Abbas T.E., Abdlhag M.A. and Mukhtar D.E. (2015). Effect of dietary yeast (Saccharomyces cerevisiae) supplementation on performance, carcass characteristics and some metabolic responses of broilers. Anim. Vet. Sci., 3 (5-1), 5-10

Akhavan-Salamat H., Ghasemi H., Khaltabadi-Farahani A.H. and Kazemi-Bonchenari M. (2011). The effects of Saccharomyces cerevisiae on performance and nutrient digestibility in broilers fed with diets containing different levels of phosphorus. Afr. J. Biotechnol., 10 (38), 7526-7533. DOI: 10.5897/AJB11.564

Al-Dobaib S.N. and Mousa H.M. (2009). Benefits and risks of growth promoters in animal production. $J$. Food Agric. Environ., 7 (2), 202-208

AOAC (2006). Official Methods of Analysis (18 ${ }^{\text {th }}$ ed.). Association of Official Analytical Chemists, Gaithersburgs MD. p. 7

Baldwin S., Hughes R.J., Hao Van T.T., Moore R.J. and Stanley D. (2018). At-hatch administration of probiotics to chickens can introduce beneficial changes in gut microbiota. PLOS ONE., 13 (13), e0194825. https://doi.org/10.1371/journal.pone.0194825

Barreto M.S.R., Menten J., Racanicci A., Pereira P.N.Z. and Rizzo P. (2008). Plant extracts used as growth promoters in broilers. Braz. J. Poult. Sci., 10 (2), 109-115

Berri C., Le Bihan-Duval E., Debut M., et al. (2007). Consequence of muscle hypertrophy on characteristics of pectoralis major muscle and breast meat quality of broiler chickens. J. Anim. Sci., 85, 2005-2011 
Berri C., Wacrenier N., Millet N. and Le Bihan-Duval E. (2001). Effect of selection for improved body composition on muscle and meat characteristics of broilers from experimental and commercial lines. Poult. Sci., 80, 833-838

Berrin K.G. (2011). Effects of probiotic and prebiotic (mannanoligosaccharide) supplementation on performance, egg quality and hatchability in quail breeders. Ankara Üniv Vet. Fak Derg., 58, 27-32

Brummer M., van Rensburg C. and Moran C.A. (2010). Saccharomyces cerevisiae cell wall products: The effects on gut morphology and performance of broiler chickens. South Afr. J. Anim. Sci., 40 (1), 14-21

Camila B., Rafael A., Ana U., Jacques N. and Luis G.B. (2012). The benefits of probiotics in human and animal nutrition, new advances in the basic and clinical gastroenterology. In: Tomasz Brzozowski (ed.), ISBN: 978-953-51-0521-3, InTech. Retrieved from: http://www.intechopen.com/books/new-advances-inthe-basic-and-clinical-gastroenterology/the-benefits-ofprobiotics-in-human-and-animal-nutrition, 28 Oct. 2001

Choi S.C., Ingale S.L., Kim J.S., Park Y.K., Kwon I.K. and Chae B.J. (2013). An antimicrobial peptide-A3: effects on growth performance, nutrient retention, intestinal and faecal microflora and intestinal morphology of broilers. Brit. Poult. Sci., 54 (6), 738-746

Chuka E. (2014). Comparative study of the effects of probiotuc and commercial enzyme on growth rate, haematology and serum biochemistry of broiler chicken. J. Food Process. Technol., 5, 367. DOI: 10.4172/2157-7710.1000367

Dim C.E., Akuru E.A., Egom M.A., et al. (2018). Effect of dietary inclusion of biochar on growth performance, haematology, and serum lipid profile of broiler birds. Agro-Science, 17 (2), 9-17

Ezema C. (2012). Probiotic Effects of Saccharomyces cerevisiae on Laying Chicken Fed Palm Kernel Cake-Based Diets. PhD Thesis, Department of Animal Health and Production, Faculty of Veterinary Medicine, University of Nigeria, Nsukka, p. 16

Ezema C. (2013). Probiotics in animal production: a review. J. Vet. Med. Anim. Health., 5 (11), 308-316. DOI: $10.5897 / J V M A H 2013.0201$

Ghasemi H.A., Tahmasbi A.M., Moghaddam G.H., et al. (2006). The effects of phytase and Saccharomyces cerevisiae (Sc47) supplementation on performance, serum parameters, phosphorus and calcium retention of broiler chicks, Int. J. Poult. Sci., 5 (2), 162-168

Ghazalah A.A., Atta A.M., Elkloub K., Moustafa M.E.L. and Shata R.F.H. (2011). Effect of dietary supplementation of organic acids on performance, nutrients digestibility and health of broiler chicks. Int. J. Poult. Sci., 10 (3), 176-184

Ghazanfar S., Anjum M.I., Azim A. and Ahmed I. (2015). Effects of dietary supplementation of yeast (Saccharomyces cerevisiae) culture on growth performance, blood parameters, nutrient digestibility and fecal flora of dairy heifers. J. Anim. Plant Sci., 25, 53-59

Ghosh T.K., Haldar S., Bedford M.R., Muthusami N. and Samanta I. (2012). Assessment of yeast cell wall as replacements for antibiotic growth promoters in broiler diets: effects on performance, intestinal histomorphology and humoral immune responses. $J$. Anim. Physiol. Anim. Nutr., 96, 275-284
Hana S.E., Tyfor M.H., Tabidi I., El Nasri M. and Mukhtar M.A. (2015). Study of different levels of yeast on performance values and immune response in broiler chicken. J. Anim. Vet. Sci., 8 (1), 1-5

Hassan S.A. and Mohammed S.F. (2014). Effects of Saccharomyces cerevisiae supplementation on growth rate and nutrient digestibility in awassi lambs fed diets with different roughage to concentrate ratios. Biochem. Biotechnol. Res., 2, 37-43

Hossain M.A., Islam A.F. and Iji P.A. (2014). Impact of microbial enzymes on growth performance, micronutrient digestibility, tissue protein contents and endogenous enzyme activities of broiler chickens fed on vegetable protein diets. Int. J. Poult. Sci., 13 (10), 555-561

Huff G.R., Huff W.E., Jalukar S., Oppy J., Rath N.C. and Packialakshmi B. (2013). The effects of yeast supplementation on turkey performance and pathogen colonization in a transport stress/Escherichia coli challenge. Poult. Sci., 92 (3), 655-662

La Ragione R.M. and Woodward M.J. (2003). Competitive exclusion by Bacillus subtilis spores of Salmonella enteric serotype Enteritidis and Clostridium perfringens in young chickens. Vet. Microbiol., 94 (3), 245-256

Mokhtari R., Yazdani A., Rezaei M. and Ghorbani B. (2010). The effects of different growth promoters on performance and carcass characteristics of broiler chickens. J. Anim. Vet. Adv., 9 (10), 2633-2639. DOI: $10.3923 /$ java.2010.2633.2639

Momoh M.O., Nwosu C.C. and Adeyinka I.A. (2010). Comparative evaluation of two Nigerian local chicken ecotypes and their crosses for growth traits. Int. J. Poult. Sci., 9(8), DOI: 10.3923/ijps.2010.738.743

Mountzouris K.C., Tsitrsikos P., Palamidi I., et al. (2010). Effects of probiotic inclusion levels in broiler nutrition on growth performance, nutrient digestibility, plasma immunoglobulins and cecal microflora compositions. Poult. Sci., 89 (1), 58-67. https://doi.org/10.3382/ps.2009-00308

Murry A.C., Murry A.C. Jr., Hinton A. and Morrison H. (2004). Inhibition of growth of Escherichia coli, Salmonella typhimurium and Clostridia perfringens on chicken feed media by Lactobacillus salivarius and Lactobacillus plantarum. Int. J. Poult. Sci., 3 (9), 603-607

Murshed M.A. and Abudabos A.M. (2015). Effects of the dietary inclusion of a probiotic, a prebiotic or their combinations on the growth performance of broiler chickens. Braz. J. Poult. Sci., S, 099-104. http://dx.doi.org/10.1590/1516-635xSpecialIssueNutritionPoultryFeedingAdditives099-104

Obi I.U. (2002). Statistical Methods of Detecting Differences between Treatment Means and Research Methodology Issues in Laboratory and Field Experiments. AP Express Publishers, Limited, 3 Obollo Road, Nsukka-Nigeria, p. 117

Ojedapo L.O., Amao S.R. and Ogunsola O.O. (2015). Variation of meat-type chickens in relation to genotypes and age of slaughter on carcass indices. $J$. New Sci., Agric. Biotechnol., 14 (6), 473-478

Olabode A.D., Onyimonyi A.E., Ezekwe A.G. and Okelola O.E. (2013). Performance characteristics and economic evaluation of laying birds fed graded levels of neem leaf meal. Int. J. Agric. Biosci., 2 (5), 213-216 
Olawumi S.O. and Fagbuaro S.S. (2011). Productive performance of three commercial broiler genotypes reared in the derived savannah zone of Nigeria. Int. J. Agric. Res., 6 (11), 798-804

Onwurah F.B., Amaefule K.U. and Ahamefule F.O. (2014). Effect of baker's yeast (Saccharomyces cerevisiae) inclusions in feed and in drinking water on performance of broiler birds. Brit. J. Appl. Sci. Technol., 4 (1), 144-151

Onyimonyi A.E., Chukwuma P.C. and Igbokwe C. (2012). Growth and hypocholesterolemic properties of dry garlic powder (Allium sativum) on broilers. Afr. J. Biotechnol., 11 (11), 2666-2671

Osita C.O., Ani A.O., Ikeh N.E., et al. (2019). Growth performance and nutrient digestibility of West African dwarf sheep fed high roughage diet containing Saccharomyces cerevisiae. Agro-Science, 18 (3), 25-28. https://dx.doi.org/10.4314/as.v18i3.5

Oyedeji J.O., Ajayi H.I. and Egere T. (2008). The effects of increasing levels of yeast culture in a high fiber diet on the performance and nutrient retention of broiler chicks. Asian J. Poult. Sci., 2 (1), 53-57

Paryad A. and Mahmoudi M. (2008). Effect of different levels of supplemental yeast (Saccharomyces cerevisiae) on performance, blood constituents and carcass characteristics of broiler chicks. Afr. J. Agric. Res., 3 (R), 835-842

Podolian J.N. (2017). Effect of probiotics on the chemical, mineral and amino acid composition of broiler chicken meat. Ukr. J. Ecol., 7 (1), 61-65. DOI: $10.15421 / 201707$

Reisinger N., Ganner A., Masching S., Schatzmayr G. and Applegate T.J. (2012). Efficacy of a yeast derivative on broiler performance, intestinal morphology and blood profile. Livestock Sci., 143, 195-200

Ritzi M.M., Abdelrahman W., Mohnl M. and Dalloul R.A. (2014). Effects of probiotics and application methods on performance and response of broiler chickens to an Eimeria challenge. Poult. Sci., 93 (11), 2772-2778. https://doi.org/10.3382/ps.2014-04207

Roto S.M., Rubinelli P.M. and Ricke S.C. (2015). An introduction to the avian gut microbiota and the effects of yeast-based probiotic-type compounds as potential feed additives. Frontiers Vet. Sci., 2 (28), 1-18. DOI: $10.3389 /$ fvets.2015.00028
Sharif M., Shoaib M., Aziz ur Rahman M., Ahmad F. and Ur Rahman S. (2018). Effect of distillery yeast sludge on growth performance, nutrient digestibility and slaughter parameters in Japanese quails. Rep., 8, 8418. DOI: 10.1038/s41598-018-26741-6

Shen Y.B., Piao X.S., Kim S.W., et al. (2009). Effects of yeast culture supplementation on growth performance, intestinal health and immune response of nursery pigs. J. Anim. Sci., 87, 2614-2620

Shim J., Seo N., Roh S., Kim J., Cha H. and Park K. (2007). Improved bread baking process using Saccharomyces cerevisiae displayed with engineered cyclodextrin glucanotransferase. J. Agric. Food Chem., 55 (12), 4735-4740

Singh V.P. and Pathak V. (2016). Comparative assessment of carcass traits in indigenous chicken. J. Anim. Res., 6 (1), 121-127

Udeh I., Ezebor P.N. and Akporahuarho P.O. (2015). Growth performance and carcass yield of three commercial strains of broiler chickens raised in a tropical environment. J. Biol., Agric. Healthcare, 5 (2), 62-67

Walker G.M. and Stewart G.G. (2016). Saccharomyces cerevisiae in the production of fermented beverages. Beverages, 2, 31-42

Yalcin S., Eser H., Yalcin S., Cengiz S. and Eltan O. (2013). Effects of dietary yeast autolysate (Saccharomyces cerevisiae) on performance, carcass and gut characteristics, blood profile, and antibody production to sheep red blood cells in broilers. $J$. Appl. Poult. Res., 22 (1), 55-61. https//doi.org/10.3382/japr.2012-00577

Yamada E.A. and Sgarbieri V.C. (2005). Yeast (Saccharomyces cerevisiae) protein concentrate: preparation, chemical composition, and nutritional and functional properties. J. Agric. Food Chem., 53 (10), 3931-3936. https://doi.org/10.1021/jf0400821

Yasar S. and Yegen M.K. (2017). Yeast fermented additive enhances broiler growth. R. Bras. Zootec., 46 (10), https://dx.doi.org/10.1590/s1806-92902017001000004

Zhang Z.F. and Kim I.H. (2014). Effects of multistrain probiotics on growth performance, apparent ileal nutrient digestibility, blood characteristics, cecal microbial shedding and excreta odor contents in broilers. Poult. Sci., 93 (2), 364-370. https://doi.org/10.3382/ps.2013-03314 